\title{
Study of Stock Market Management in Reference to Institutional Investment
}

\author{
Naresh Kedia*, Anil Vashisht \\ Amity Business School (ABS), Amity University Madhya Pradesh, India
}

Received July 18, 2021; Revised August 19, 2021; Accepted September 21, 2021

\section{Cite This Paper in the following Citation Styles}

(a): [1] Naresh Kedia, Anil Vashisht, "Study of Stock Market Management in Reference to Institutional Investment," I Universal Journal of Accounting and Finance, Vol. 9, No. 5, pp. 1019 - 1023, 2021. DOI: 10.13189/ujaf.2021.090512.

(b): Naresh Kedia, Anil Vashisht (2021). Study of Stock Market Management in Reference to Institutional Investment. Universal Journal of Accounting and Finance, 9(5), 1019 - 1023. DOI: 10.13189/ujaf.2021.090512.

Copyright $(2021$ by authors, all rights reserved. Authors agree that this article remains permanently open access under the terms of the Creative Commons Attribution License 4.0 International License

\begin{abstract}
The institutional investors, whether the DII (Domestic Institutional Investor) or FII (Foreign Institutional Investor) contribute to the growth and management of stock market. The stock market is very dynamic in nature and the volatility is prevalent across. It is important to understand the relation of different institutional investors on the stock market. Foreign institutional investors and Domestic institutional investors are two major sources from which the stock market receives its investment. Thereby, it is necessary to understand the cause and effect of these investments on the stock market. The flow of fund from the foreign investors is one of the reasons for the growth of Indian Stock Market. The cause-and-effect study gives us a better picture of the stock market movement and this study focuses on finding the same. The study will help investors and stockbrokers to understand the movement of the stock market in a better way. In this study, cause and effect between the FIIs, DIIs and Stock Market returns is analysed. The statistical tools used for analysis are Granger Causality test and Johansen Co-integration test. Both the statistical tool used are reliable and the expected results will be highly beneficial for the investors at large. The results shows that there is cause and effect relation between the FII and DII, but the co-integration between the FIIs, DIIs and stock market is absent. The study will contribute in understanding the behavior of stock market.
\end{abstract}

Keywords Stock Market, Institutional Investment, Foreign Funds

\section{Introduction}

The Indian Stock Market is interlinked with the changes happening around the globe. We live in a globalized world which runs on ripple effect. The ripple effects explain that any effect anywhere in the world will impact other countries too. Similarly, through world events or through overseas investment in stock market, the dependence of stock market on the foreign funds has increased. The stock markets are functioning as a single complex system and are an important component to evaluate the growth of the overall economy. That is why the government, central bank and industries of an economy keep a close check on the happening of stock market. The development of a nation is directly related to its economy which includes various factors such as GDP, interest rates, inflation rate etc. The domestic institutions whether it is a mutual fund company, an asset management company or hedge funds, they all invest in stock market in large volumes, so it is very significant to know the relation of these entities with the stock market of India.

The stock markets in India are attracting large volume of investment from the Domestic Institutional Investors and the Foreign Institutional Investors. The entry of foreign funds into domestic capital market has raised various uncertainties related to Foreign Institutional Investor's portfolio choice and performance. Although, obstacle to foreign investment in developing markets have reduced to a large extent due to liberalization. Because of the flexible policy by the government post liberalization, the flow of funds from the foreign players has increased that has benefitted the stock market as well. The market 
capitalization has increased, and stock markets have introduced range of instruments for investment. Financial engineering has taken place for developing new instruments.

[1]The findings of several studies have shown that FIIs and DIIs such as (Loomba, 2012) and (French, 2011) helping in boosting the economy by increasing the foreign exchange reserves and shows a significant impact on the stock market. FIIs bear various kinds of business risks as well as political risk as it adds uncertainty to capital market. Due to this reason Foreign Institutional Investors do not receive the same favorable treatment as domestic investors get. The unpredictability of proceeds has developed into a big issue for the researchers in financial market. The DIIs are wary of the FIIs as the investment scenario is very unpredictable.

In this research, we have established the cause-and-effect relation among DIIs and FIIs and result of both on the Indian Stock Market. The understanding whether the DIIs are affected with the FIIs or vice-versa will give us an understanding on the movement of the market.

\section{Review of Literature}

[2] (Amadou, 2011) In the research author examined the bang of foreign investment on domestic savings in Togo. In this research data has been considered for 38 years from 1970 to 2008 . For analysing the data, the author used some techniques i.e. unit root, co-integration, augmented dickey-fuller (ADF). After analysing the findings are indigenous investments are comparatively insignificant, foreign investment can subsist used as a tool for domestic savings, the outcomes derived commencing 1970 to 2008 shows that overall foreign investment influences optimistically \& extensively domestic investment, the consequence of portfolio asset is negative. [3] (Aurangzeb \& Ul Haq, 2012) In this research, authors examine to investigate the effect of savings on the economic expansion of Pakistan, in this research information has been occupied from the period of 1981 to 2010. For analysing the data, used multi regression technique. After analysing finding is that all independent variables have positive impact on the economic growth. [4] (Chaudhary \& Mahmood, 2012) This research examined how Foreign Investment impacting Domestic Investment in Pakistan. They collected data from World Bank of both foreign and domestic investment for a period of 38 years from 1972 to 2010. They have analysed the data by using ARDL co-integration technique and the consequences demonstrate that there survives a short run and long run interconnection in the representation. FDI and economic development have the positive \& important effect on the domestic savings. So, consequences establish that FDI has an corresponding impact on the indigenous investment in
Pakistan. [5] (Lautier \& Moreaub, 2012) This manuscript studies the effect of domestic asset on FDI investment in developing countries using a huge example for the phase 1984-2004. This research has several studies on the impact of FDI on development and savings in host-country, but the integration among FDI and domestic investment is bi-directional. Although, very low is identified about how domestic investment itself affects FDI inflows. [6] (Ali, 2014), conducted a study, Impact of foreign savings on the volatility of stock market. This study inspects the impact of FDI on the stock market also factor that lead to the development of stock market by using the tools co-integration test. This study examines by collecting the data from Karachi stock exchange by taking the variable exchange rate, GDP, GNP. This learning demonstrates that there is optimistic relation between the FDI, GDP, GNP, inflation in the stock market development. [7] (Gandhi, 2015) Granger's causality test was used to investigate the dynamic connection among foreign institutional contributions as well as the Indian stock market in this research. The empirical research demonstrates that institutional ownership investments in the Indian stock market have a causal relationship. Since FIIs have played such a large role in propelling the Indian stock market in recent years, they have had at most one-third of all assets under custodianship at any one time. However, they are in a rush for short-term profit, therefore they often transfer money. However, the findings are preliminary, and further study is required to fully address the problem. [8] (Olugbenga \& Grace) stated in the study about the impact of foreign direct investment on Nigerian stock market development by using data of 40 years (1970-2010) and they applied Ordinary Least Square, Multiple regressions technique, Standard Error Test, Unit Root Test \& Johansen Co-integration investigation. The authors have found a positive and significant Association among foreign direct savings and Nigerian capital market improvement in short run and Co-integration test revealed absence of long run relationship among foreign direct investment \& stock market expansion in Nigeria. The objectives of the study based on the review of literature is to study whether FIIs are impacting on DIIs investment and vice-versa and to understand the impact of FIIs and DIIs on the stock market indices.

\section{Research Methodology}

\subsection{Sample Period and Sources of Data Collection}

The period of study is from January 2014 to December 2019. commencing the literature, it has been experiential that the learning of interaction between the FII and DII on Indian stock market no major data is necessary. So, this learn will be founded in derivative data. 


\subsection{Data Analysis}

\subsubsection{Unit Root Test (Augmented Dickey Fuller Test)}

This test is conducted for time sequence data. The ADF in this test is worn as a harmful digit. The high negative it is, the higher the negative response of null hypothesis. It is used to check whether a changeable incorporated in the representation is motionless or non- stationary".

The first different result of the test is taken into consideration which shows that the FIIs, DIIs and the stock price returns shows stationary.

Augmented Dickey-Fuller unit root tests values at 5\% first difference.

\section{Domestic Institutional Investors}

1. Intercept: The result in the table 1 shows that at first difference in intercept equation, the absolute value (26.59) is more than $5 \%$ essential value (2.86) \& $\mathrm{p}$-value is fewer than the critical value, Consequently, the null proposition of unit root is discarded at stage representing stationary in information of DIIs.

2. Trend \& Intercept: The result in the table 1 shows that at the first difference in intercept $\&$ trend equation, the absolute value (26.58) is more than $5 \%$ critical value (3.41) and p-value is fewer than the significant value, consequently, the null hypothesis of component root is discarded at level representative stationary in data of DIIs.

Foreign Institutional Investors

1. Intercept: The result in the table 1 shows that, at the first difference in intercept equation, the absolute value (23.29) is more than $5 \%$ essential value (2.86) and $\mathrm{p}$-value is fewer than the critical value, Therefore, the null hypothesis of unit root is rejected at level indicating stationarity in data of DIIs.
2. Trend \& Intercept: The result in the table 1 shows that at first difference in intercept \& trend equation, the absolute value (23.29) is more than $5 \%$ critical value (3.41) and p- value is less than the critical value, Therefore, the null hypothesis of unit root is rejected at level indicating stationarity in data of FIIs.

\section{Stock Market Price}

1. Intercept: The result in the table 1 shows that at first difference in intercept equation, the absolute value (40.78) is more than $5 \%$ critical value (2.86) and $\mathrm{p}$-value is less than the critical value, Therefore, the null hypothesis of unit root is rejected at level indicating stationarity in data of stock price.

2. Trend \& Intercept: The result in the table shows that at first difference in intercept \& trend equation, the absolute value (40.78) is more than $5 \%$ critical value (3.41) and $p$ - value is less than the critical value, Therefore, the null hypothesis of unit root is rejected at level indicating stationarity in data of stock price.

Therefore, from the below table and analysis from first difference model of ADF test, all the three variables i.e., DIIs, FIIs and Stock Price are stationary and ready for testing the granger causality.

\subsubsection{Granger Causality Tests}

Granger causality examination is a numerical test to establish whether one instance series is helpful for forecasting an additional. This test is based on the supposition that variables are stationary and this can subsist check with the help of ADF (Unit Test).

Null Hypothesis - There is no causality between FII, DII and stock return.

Alternative Hypothesis - There is causality between FII, DII and stock Market Price.

Table 1. Unit Root Test (Augmented Dickey Fuller Test)

\begin{tabular}{|c|c|c|c|c|c|c|c|c|c|}
\hline \multicolumn{10}{|c|}{ First Difference } \\
\hline & \multicolumn{3}{|c|}{ Intercept } & \multicolumn{3}{|c|}{ Trend \& Intercept } & \multicolumn{3}{|c|}{ None } \\
\hline Variables & Critical & Absolute & P- & Critical & Absolute & P- & Critical & Absolute & $\mathrm{P}-$ \\
\hline & Value & Value & value & Value & Value & Value & Value & Value & value \\
\hline$\overline{\text { DII }}$ & 2.86 & 26.59 & 0 & 3.41 & 26.58 & 0 & 1.94 & 26.60 & 0 \\
\hline FII & 2.86 & 23.29 & 0 & 3.41 & 23.29 & 0 & 1.94 & 23.30 & 0 \\
\hline Stock & 2.86 & 40.78 & 0 & 3.41 & 40.78 & 0 & 1.94 & 40.75 & 0 \\
\hline Price & & & & & & & & & \\
\hline Return & & & & & & & & & \\
\hline
\end{tabular}


Table 2. Pairwise Granger Causality Tests

Sample: 01/01/2014 12/31/2019

Lags: 7

\begin{tabular}{|c|c|c|c|}
\hline Null Hypothesis: & Obs & F-Statistic & Prob. \\
\hline DII_RS_CRORE_does not Granger Cause FII_RS_CRORE_ & 1240 & 4.84352 & 2.E-05 \\
\hline FII_RS_CRORE_does not Granger Cause DII_RS_CRORE_ & & 17.6114 & 9.E-23 \\
\hline "STOCK_PRICE does not Granger Cause FII_RS_CRORE_ & 1240 & 23.6784 & 5.E-31 \\
\hline FII_RS_CRORE_does not Granger Cause STOCK_PRICE” & & 1.70081 & 0.1044 \\
\hline STOCK_PRICE does not Granger Cause DII_RS_CRORE_ & 1240 & 22.9249 & 5.E-30 \\
\hline DII_RS_CRORE_does not Granger Cause STOCK_PRICE & & 1.31694 & 0.2380 \\
\hline
\end{tabular}

Granger causality test has been used in the financial research. There are different possibilities of causality among variables that the variables are unidirectional causality, bidirectional causality or no causality. Test result states as per Table 2 that FII and DII have bidirectional causality they affect each other. There is unidirectional causality among the stock price with FII \& DII and there is no causality involving the stock market change and FII and DII.

\subsubsection{Johansen Co-integration Test}

This test is used to know that weather data is co-integrated between variables. This test allows additional than one co-integration association. So, it is additional appropriate than the Engle-Granger which is supported on the Dickey-Fuller or the increased test for element roots in the residuals commencing the solitary co-integration connection.

\section{Hypothesis}

Null Hypothesis - There is no co-integration.

Alternative Hypothesis- There is co-integration

Table 3. Johansen Co-integration Test

"Included observations: 1240

Trend assumption: Linear deterministic trend

Series: DII_RS_CRORE_FII_RS_CRORE_STOCK PRICE

Lags interval (in first differences): 1 to 7

Unrestricted Cointegration Rank Test (Trace)

\begin{tabular}{ccccc}
\hline $\begin{array}{c}\text { Hypothesized } \\
\text { No. of CE(s) }\end{array}$ & Eigenvalue & $\begin{array}{c}\text { Trace } \\
\text { Statistic }\end{array}$ & $\begin{array}{c}0.05 \\
\text { Critical Value }\end{array}$ & Prob.** \\
& & & & \\
\hline None * & 0.095956 & 310.3236 & 29.79707 & 0.0001 \\
At most 1 & 0.057925 & 115.4282 & 15.49471 & 0.0001 \\
At most 2 & $7.55 \mathrm{E}-05$ & 0.145939 & 3.841466 & 0.7024 \\
\hline
\end{tabular}

Trace test indicates 2 cointegrating eqn(s) at the 0.05 level $*$ denotes rejection of the hypothesis at the 0.05 level ***MacKinnon-Haug-Michelis (1999) p-values

Unrestricted Cointegration Rank Test (Maximum Eigenvalue)

\begin{tabular}{ccccc}
\hline $\begin{array}{c}\text { Hypothesized } \\
\text { No. of CE(s) }\end{array}$ & Eigenvalue & Statistic & Critical Value & Prob.** \\
& & & & \\
\hline None * & 0.095956 & 194.8954 & 21.13162 & 0.0001 \\
At most 1* & 0.057925 & 115.2822 & 14.26460 & 0.0001 \\
At most 2 & $7.55 \mathrm{E}-05$ & 0.145939 & 3.841466 & 0.7024 \\
\hline
\end{tabular}

Max-eigenvalue test indicates 2 cointegrating eqn(s) at the 0.05 level * denotes rejection of the hypothesis at the 0.05 level **MacKinnon-Haug-Michelis (1999) p-values"

In this study Johansen co-integration test was worn in the financial research. A co-integration test is used to see that weather data is co-integrated between variables or not. Johansen test for co-integration on all the variables in the series with 7 lag selection intervals showed that the combination of all variables is co-integrated. The result shows in the table 3 that trace statistics (310.3) is greater than (29.79) critical value and Max-Eigen value (194.89) is greater than (21.13) critical value. This shows that all the variables are co-integrated.

\section{Results}

The results of the study are very significant. The result of the study shows that there is a cause-and-effect relationship between the Foreign Institutional Investors (FIIs) and Domestic Institutional Investors (DIIs). They have bidirectional casuality i.e. they both affect each other (Jayaraj, Murale, \& Christy, 2009). [9] FIIs and DIIs does not affect stock market price i.e., they have no causality but there are many other variables that are affecting stock market price. (Jayaraj, Murale, \& Christy, 2009) There is co-integration between FIIs, DIIs and Stock price. This means there is a durable association among these variables. The presence of the co-integration between the Foreign Institutional Investors, Domestic Institutional Investors and Stock market clearly gives us the understanding that they are integrated. 


\section{Conclusions}

Indian stock market has seen significant development in the last five years that makes the market same as the market in developed countries. To an extent, the development of the economy may be cited from the development of the stock market. The Indian stock market has grown by leaps and bounds after the LPG (Liberalization, Privatization and Globalization) and the study concludes that the FIIs and DIIs investment in the stock market are co-integrated which implies that they are related to one another. The significant characteristics of the developed market are that the flow of institutional investor is more. This paper set outs to find whether FIIs and DIIs impact Indian stock market as well as each other. The findings reveal that there is an absence of link between FIIs, DIIs and stock market price. They are not exerting influence on the stock market price of Indian stock market but there is a link between FIIs and DIIs. The cointegration between the foreign institutional investors, domestic institutional investors and the stock market make the stock market more dynamic, and the results will help us understand the movement of the stock market in a better way.

\section{REFERENCES}

[1] Loomba, J., "Do FIIs impact volatility of Indian Stock Market?" The International Journal of Marketing, Financial services \& Management Research, vol. 1, no. 7, pp. 80-93, 2012.

[2] French, J. J., "The Dynamic Interaction between Foreign Equity Flows and Returns: Evidence from The Johannesburg Stock Exchange," The International Journal of Business and Finance Research, vo. 5, no. 4, pp. 45-56, 2011.

[3] Amadou, A., "The Effect of Foreign Capital on Domestic Investment in Togo," International Journal of Economics and Finance, Vol. 3, No. 5 pp. 223-226, 2011.

[4] Chaudhary, A., \& Mahmood, H., "Foreign Direct Investment-Domestic Investment Nexus in Pakistan." Middle East Journal of Scientific Research, Vol. 11, No. 11, pp. 1500-1507, 2012.

[5] Lautier, M., \& Moreaub, F., "Domestic Investment and FDI in Developing Countries: The Missing Link," Journal of Economic Development Vol. 37, No. 3, pp. 1-23, 2012.

[6] Ali, I., "Impact of Foreign Direct Investment on Stock Market Volatility," Journal of Business and Management, Vol. 16 No. 1, pp. 77-80, 2014

[7] Gandhi, D. K., “A Study of Foreign Institutional Inflows and Indian Stock Market Volatility," IJSR International Journal of Scientific Research Vol. 4, No. 5, pp. 3-6, 2015.

[8] Olugbenga, A. A., \& Grace, O. O., "Impact of Foreign Direct Investment on Nigerian Capital Market Development," International Journal of Academic Research in Accounting, Finance and Management Sciences, Vol. 5, No. 1, pp. 103-108, 2015.

[9] Jayaraj, Murale, V. and Christy P., "An Empirical Investigation of Impact of Net FII Investment on Performance of Indian Stock market of BSE," Journal of Contemporary in Management, pp.125-143. 2009. 